\title{
Evaluation of Various Genotypes of Tomato (Solanum lycopersicum L.) on Quality Traits under Temperate Conditions of Kashmir
}

\author{
B. Srinivasulu, M. Rashid, P. Pradeep Kumar, D. Srikanth, P.K. Singh
}

10.18805/ag.D-5412

\begin{abstract}
Background: Tomato is one of the most important vegetable crop grown in the world. Identification of better genotypes among the existing germplasm leads to the success of breeding programme. Elite genotypes should be known for our trait of interest.

Methods: A field experiment was carried out at Vegetable Experimental Field, SKUAST-K, Shalimar, Srinagar during Kharif-2018 in which twenty seven genotypes of tomato (Solanum lycopersicum L.) were evaluated to estimate the performance of genotypes on various quality traits like lycopene content, titrable acidity, ascorbic acid content, total soluble solids and juice to pulp ratio.

Result: Analysis of variance revealed significant differences among the genotypes for all the traits under studied. Highest lycopene content was recorded in the genotypes 2015/TODHYB-1, Roma and VRT-19 Whereas highest TSS content was exhibited by Kashi Aman, Roma, Jawahar-99 and Shalimar Hybrid Tomato-1. Highest titrable acidity recorded in Marglobe followed by 2015/TODHYB-4 and Kashi Hemanth. Juice to pulp ratio was highest in the genotypes namely, 2016/TODVAR-5 and Kashi Vishesh. Hence, the best performed genotypes can be used as such in promotion of tomato production programme as elite germplasm lines/varieties or may be recommended for commercial cultivation after testing them over years and locations.
\end{abstract}

Key words: Genotypes, Juice to pulp ratio, Lycopene content, Titrable acidity, Tomato.

\section{INTRODUCTION}

India is the second largest producer of vegetables in the world after china. In horticulture production, vegetables having the share of about $59.3 \%$. Tomato is the world's largest vegetable crop after potato and onion. In India, Madhya Pradesh leads in production followed by Karnataka, Andhra Pradesh, Tamil Nadu and Gujarat. During 2018-19, India produced 20.51 million metric tonnes of tomato in an area of about 0.81 million hectares (NHB, $1^{\text {st }}$ Advance estimates, 2018-19).

Tomato (Soalanum lycopersicum L.) is an important member of Solanaceae family having chromosome number of $2 n=2 x=24$. It is the third most important vegetable crop in India, next to potato and onion. The probable ancestor of tomato is Solanum lycopersicum var. cerasiforme Bailey. It is originated in wild form in the Peru Equador region of Andes (South America). It is a day neutral plant and is mainly self pollinated, but a certain percentage of cross pollination also occurs (Depra et al., 2014). Tomato is a good source of minerals, vitamins, organic acids, lycopene, beta-carotne, phenols and flavonoids. Tomato fruit provides $3-4 \%$ total sugar, 4-7\% total solids, $15-30 \mathrm{mg} / 100 \mathrm{~g}$ ascorbic acid, $7.5-$ $10 \mathrm{mg} / 100 \mathrm{ml}$ titrable acidity, $6-8 \mathrm{mg} / 100 \mathrm{~g}$ lycopene and 0.5-2.5/100g beta carotene (Chada, 2019). Lycopene, which is a powerful anti-oxidant, is involved in reducing the risk of cardiovascular diseases and some types of cancer (Chada, 2019).

India is the source of various genotypes of tomato. Identification of superior genotypes among the existing
Division of Vegetable Science, Sher-e-kashmir university of Agricultural Sciences and Technology, Shalimar, Srinagar-190 001, Jammu and Kashmir, India.

Corresponding Author: B. Srinivasulu, Department of Vegetable Science, College of Horticulture, Dr. Y.S.R. Horticultural University, West Godavari-534 101, Andhra Pradesh, India.

Email: srinivasbiyyala333@gmail.com

How to cite this article: Srinivasulu, B., Rashid, M., Kumar, P.P., Srikanth, D. and Singh, P.K. (2021). Evaluation of Various Genotypes of Tomato (Solanum lycopersicum L.) on Quality Traits under Temperate Conditions of Kashmir. Agricultural Science Digest. DOI: 10.18805/ag.D-5412.

Submitted: 09-06-2021 Accepted: 08-09-2021 Online: 17-09-2021

germplasm becomes extremely important for future breeding programme.

\section{MATERIALS AND METHODS}

The present investigation was carried out at Vegetable Experimental Farm of Division of Vegetable Science, SKUAST-Kashmir, Shalimar, Srinagar during summer 2018. The site is situated $34^{\circ} \mathrm{N}$ of latitude and $74.89^{\circ} \mathrm{E}$ of longitude. The climate is temperate characterized by mild summers. June and July are the hottest months while January and February are the coldest. The maximum rainfall is received during March to April. Twenty seven diverse genotypes of tomato were evaluated in a randomized complete block design (RCBD) with three replications, such 
that there were 81 treatments in total (details of genotypes along with their source are given in the Table 1). The spacing followed for the row to row and plant to plant distance is 60 $x 35 \mathrm{~cm}$. the experimental field was well prepared and standard cultural and plant protection measures were followed to raise a healthy crop. Analysis of variance was carried out as per the procedure given by Panse and Sukhatme (1985).

\section{Total soluble solids (\%)}

The total soluble solids (TSS) contents of the fruits were measured with the help of hand refractometer. Tomato juice was collected from red ripen fruits. A drop of juice was placed over the prism of digital refractometer and was noted in per cent.

\section{Titrable acidity (\%)}

Acid content of the extracted juice was determined by titrating $5 \mathrm{ml}$ of juice against $\mathrm{N} / 10 \mathrm{NaOH}$ using Phenolphthalein as an indicator. Acidity was expressed in term of anhydrous citric acid (A.O.A.C.1960) per $100 \mathrm{ml}$ of tomato juice.

\section{Ascorbic acid content (mg/100g)}

Ascorbic acid content was determine by 2,6-dichlorophenol indophenol titration method (A.O.A.C.1960) and expressed in $\mathrm{mg} / \mathrm{100 \textrm {g }}$ of fruits.

\section{Lycopene content $(\mathbf{m g} / \mathbf{1 0 0 g})$}

Total lycopene content of tomato was determined by the method of Lee (2001) with some modifications. With the help of moral and pestle $5 \mathrm{~g}$ of tomato pulp was crushed in acetone, till it became colourless. Then the extracted solution was poured into a separating funnel. Then added, petroleum ether and small amount of sodium sulphate and shaken rigorously for mixing well. Then the separating funnel was kept undisturbed to separate the lycopene pigment from the acetone to petroleum ether layer. After that, coloured solution was separate in a $500 \mathrm{ml}$ volumetric flask and the volume will be adjusted with petroleum ether. Finally, the sample absorbance was measured at $503 \mathrm{~nm}$ in a spectrophotometer, using the petroleum as blank. The results were expressed as $100 \mathrm{~g}^{-1} \mathrm{FW}$ (fresh weight) basis.

Lycopene content $(\mathrm{mg} / 100 \mathrm{~g})=$

$$
\frac{3.1206 \times \text { Vol. made up } \times \text { Dilution }}{\text { Weight of sample }} \times 100
$$

\section{Juice to pulp ratio}

A composite sample of $500 \mathrm{~g}$ of fruit was taken from the randomly selected plants from each replication and crushed thoroughly in an electrically operated juice extractor. The extract was filtered through dry muslin cloth and the filtrate was collected in the weighed beaker. The weight of juice along with the beaker was recorded and juice content was calculated as

Juice content $=$ (juice + beaker) weight-beaker weight Pulp content was calculated as :

$$
\text { Pulp content }=\text { Fruit weight }- \text { Juice weight }
$$

\section{RESULTS AND DISCUSSION}

The data recorded on five qualitative traits were subjected to analysis of variance to test the significance of difference among the genotypes. Analysis of variance presented in Table 2, showed that the mean square due to genotypes were highly significant for all the traits. Mean performance of the various genotypes for the quality traits in tomato are presented in Table 3.

\section{Total soluble solids (\%)}

Total soluble solid (\%) ranged from 3.20\% (2016/TODVAR-2) to $6.23 \%(2015 /$ TODHYB-4) with the mean value of $4.46 \%$. Top ranking genotypes as compared to mean are Kashi Aman (4.93\%), Jawahar-99 (4.86\%), Kashi Vishesh (4.80\%), Sel.7 (4.73\%), whereas the genotypes 2016/TODVAR-10 (3.93\%), Kashi Hemanth (3.90\%), VRT-01 and 2015/ TODHYB-1 (3.80\%) were showed significantly lower value. The results are in agreement with the findings of Neeraj Singh et al. (2015) and Pradeep Kumar et al. (2001).

\section{Lycopene content $(\mathrm{mg} / \mathbf{1 0 0 g})$}

The lycopene content ranged from $6.80 \mathrm{mg} / 100 \mathrm{~g} \mathrm{(2016/}$ TODVAR-12) to $18.50 \mathrm{mg} / 100 \mathrm{~g}$ (Kashi Aman) with the general mean of $12.13 \mathrm{mg} / 100 \mathrm{~g}$. The genotypes namely

Table 1: List of genotypes of tomato (Solanum lycopersicum L.)

\begin{tabular}{|c|c|}
\hline Genotype/variety & Source \\
\hline Kashi Hemanth & IIVR (Varanasi) \\
\hline Kashi Amrit & IIVR (Varanasi) \\
\hline Kashi Sharad & IIVR (Varanasi) \\
\hline Kashi Vishesh & IIVR (Varanasi) \\
\hline Kashi Chayan & IIVR (Varanasi) \\
\hline Kashi Aman & IIVR (Varanasi) \\
\hline Kashi Anupam & IIVR (Varanasi) \\
\hline TOLCV-16 & IIVR (Varanasi) \\
\hline TOLCV-28 & IIVR (Varanasi) \\
\hline TOLCV-32 & IIVR (Varanasi) \\
\hline VRT-01 & IIVR (Varanasi) \\
\hline VRT-19 & IIVR (Varanasi) \\
\hline VRT-13 & IIVR (Varanasi) \\
\hline Sel-7 & IIVR (Varanasi) \\
\hline Jawahar-99 & IIVR (Varanasi) \\
\hline 2016/TOVDVAR-12 & AICRP, IIVR (Varanasi) \\
\hline 2016/TODVAR-11 & AICRP, IIVR (Varanasi) \\
\hline 2016/TODVAR-1 & AICRP, IIVR (Varanasi) \\
\hline 2016/TODVAR-3 & AICRP, IIVR (Varanasi) \\
\hline 2016/TODVAR-10 & AICRP, IIVR (Varanasi) \\
\hline 2016/TODVAR-5 & AICRP, IIVR (Varanasi) \\
\hline 2016/TODVAR-2 & AICRP, IIVR (Varanasi) \\
\hline 2015/TODHYB-4 & AICRP, IIVR (Varanasi) \\
\hline 2015/TODBYB-1 & AICRP, IIVR (Varanasi) \\
\hline Roma & SKUAST-K, Shalimar \\
\hline Shalimar Hybrid Tomato-1 & SKUAST-K, Shalimar \\
\hline Marglobe & SKUAST-K, Shalimar \\
\hline
\end{tabular}
used in the experimental design. 
2015/TODHYB-1 (16.80 mg/100g), VRT-19 (15.06 mg/ $100 \mathrm{~g})$, TOLCV-28 (14.56 mg/100g), VRT-13 (14.36 mg/100g) and Kashi Anupam (13.60 mg/100g), have exhibited significantly highest lycopene content as compared to general mean, whereas the genotypes viz., 2016/TODVAR5 (10.63 mg/100g), Kashi Hemanth (10.23 mg/100g), Kashi Amrit (9.36 mg/100g), Kashi Chayan, Jawahar-99 (8.70 mg/ $100 \mathrm{~g})$ and $2016 /$ TODVAR-3 $(7.90 \mathrm{mg} / 100 \mathrm{~g})$ had lowest lycopene content as compared to general mean. The results are in agreement with the earlier findings of Gonalez-Cebrino et al. (2011).

\section{Ascorbic acid content $(\mathbf{m g} / \mathbf{1 0 0 g})$}

The ascorbic acid content ranges from $18.73 \mathrm{mg} / 100 \mathrm{~g}$ (Marglobe) to $29.30 \mathrm{mg} / 100 \mathrm{~g}$ (Kashi Chayan) with the mean value of $22.91 \mathrm{mg} / 100 \mathrm{~g}$. The genotypes Kashi Hemanth

Table 2: Analysis of variance for the quality traits in tomato (Solanum lycopersicum L.).

\begin{tabular}{lccc}
\hline \multirow{2}{*}{ Character } & \multicolumn{3}{c}{ Mean sum of squares } \\
\cline { 2 - 4 } & Replication & Treatments & Error \\
\hline d.f & 2 & 26 & 52 \\
Total soluble solids $(\%)$ & 0.0509 & $1.3094^{\star *}$ & 0.0270 \\
Lycopene content $(\mathrm{mg} / 100 \mathrm{~g})$ & 0.0075 & $29.8218^{\star *}$ & 0.0400 \\
Ascorbic acid content $(\mathrm{mg} / 100 \mathrm{~g})$ & 0.0208 & $35.6402^{\star *}$ & 0.0365 \\
Titrable acidity $(\%)$ & 0.0001 & $0.0140^{\star *}$ & 0.0003 \\
Juice to pulp ratio & 0.0004 & $0.0387^{\star *}$ & 0.0003 \\
\hline
\end{tabular}

** Significant at 1 per cent level.

Table 3: Mean performance of the various genotypes for the quality traits in tomato (Solanum lycopersicum L.).

\begin{tabular}{|c|c|c|c|c|c|}
\hline Genotypes & $\begin{array}{l}\text { Total soluble } \\
\text { solids(\%) }\end{array}$ & $\begin{array}{c}\text { Lycopene } \\
\text { content(mg/100g) }\end{array}$ & $\begin{array}{c}\text { Ascorbic acid } \\
(\mathrm{mg} / 100 \mathrm{~g})\end{array}$ & $\begin{array}{c}\text { Titrable Acidity } \\
(\%)\end{array}$ & $\begin{array}{l}\text { Juice to } \\
\text { pulp ratic }\end{array}$ \\
\hline Kashi Hemanth & 3.90 & 10.23 & 26.26 & 0.35 & 0.50 \\
\hline Kashi Aman & 4.93 & 18.50 & 19.30 & 0.32 & 0.64 \\
\hline Kashi Amrit & 5.53 & 9.36 & 20.10 & 0.16 & 0.44 \\
\hline Kashi Vishesh & 4.80 & 13.30 & 20.60 & 0.26 & 0.66 \\
\hline Kashi Anupam & 3.86 & 13.60 & 22.60 & 0.17 & 0.62 \\
\hline Kashi Chayan & 5.20 & 8.70 & 29.30 & 0.25 & 0.47 \\
\hline Kashi Sharad & 4.20 & 11.26 & 28.80 & 0.32 & 0.48 \\
\hline VRT-01 & 3.80 & 15.43 & 19.53 & 0.23 & 0.41 \\
\hline VRT-13 & 4.96 & 14.36 & 21.33 & 0.17 & 0.37 \\
\hline VRT-01 & 3.80 & 15.43 & 19.53 & 0.23 & 0.41 \\
\hline Tolcv-16 & 4.70 & 10.90 & 23.93 & 0.22 & 0.47 \\
\hline Tolcv-28 & 4.36 & 14.56 & 25.13 & 0.32 & 0.45 \\
\hline Tolcv-32 & 4.40 & 8.23 & 21.36 & 0.37 & 0.59 \\
\hline Sel-7 & 4.73 & 11.23 & 24.73 & 0.25 & 0.32 \\
\hline Jawahar-99 & 4.86 & 8.70 & 24.86 & 0.31 & 0.37 \\
\hline 2016/TODVAR-1 & 4.10 & 8.33 & 25.63 & 0.32 & 0.51 \\
\hline 2016/TODVAR-2 & 3.20 & 16.96 & 21.63 & 0.36 & 0.56 \\
\hline 2016/TODVAR-3 & 4.03 & 7.90 & 20.30 & 0.25 & 0.65 \\
\hline 2016/TODVAR-5 & 4.06 & 10.63 & 24.90 & 0.33 & 0.71 \\
\hline 2016/TODVAR-10 & 3.93 & 10.33 & 23.93 & 0.32 & 0.39 \\
\hline 2016/TODVAR-11 & 3.90 & 9.56 & 25.10 & 0.32 & 0.46 \\
\hline 2016/TODVAR-12 & 3.76 & 6.80 & 20.80 & 0.26 & 0.56 \\
\hline 2015/TODHYB-1 & 3.80 & 16.89 & 20.73 & 0.23 & 0.64 \\
\hline 2015/TODHYB-4 & 6.23 & 16.43 & 19.30 & 0.37 & 0.53 \\
\hline Shalimar Hybrid Tomato-1 & 4.83 & 8.36 & 21.70 & 0.26 & 0.56 \\
\hline Roma & 4.93 & 16.33 & 19.66 & 0.28 & 0.27 \\
\hline Marglobe & 4.23 & 15.73 & 18.73 & 0.46 & 0.42 \\
\hline Mean & 4.46 & 12.13 & 22.91 & 0.28 & 0.50 \\
\hline CV & 3.68 & 1.57 & 0.87 & 6.66 & 3.65 \\
\hline C.D. $5 \%$ & 0.26 & 0.31 & 0.32 & 0.03 & 0.02 \\
\hline C.D. $1 \%$ & 0.35 & 0.41 & 0.43 & 0.04 & 0.03 \\
\hline
\end{tabular}


(26.26 mg/100g), 2016/TODVAR-1 (25.63 mg/100g), Jawahar-99 (24.86 mg/100g), Sel.7 $(24.73 \mathrm{mg} / 100 \mathrm{~g})$ and TOLCCV-16 (23.93 mg/100g) were showed significantly highest ascorbic acid as compared to general mean. The genotypes viz., Kashi Aman (19.30 mg/100g), 2015/ TODHYB-4 (19.30 mg/100g), VRT-01(19.53 mg/100g), Kashi Anupam (22.60 mg/100g), 2016/TODVAR-12 (22.80 $\mathrm{mg} / 100 \mathrm{~g}$ ) had lowest ascorbic acid content. These results are in agreement with the earlier findings of George et al. (2004) and Kaur et al. (2002).

\section{Titrable acidity (\%)}

The highest and lowest titrable acidity was observed in Marglobe (0.46\%) and Kashi Amrit (0.16\%). The general mean for this trait was $0.28 \%$. The genotypes namely, 2015/ TODHYB-4 (0.37\%), Kashi Hemanth (0.35\%), TOLCV-28 (0.32\%), 2016/TODVAR-11 (0.32\%), Jawahar-99 (0.31\%), were showed significantly highest titrable acidity as compared to general mean, whereas the genotypes viz., VRT-13, Kashi Anupam (0.17\%), VRT-19, 2016/TODVAR-3 $(0.25 \%), 2015 /$ TODHYB-1 $(0.43 \%)$ were showed significantly lowest titrable acidity. The results are in agreement with the findings of Toor et al. (2006) and Pradeep Kumar et al. (2001).

\section{Juice to pulp ratio}

The highest and lowest values for the trait juice to pulp ratio was recorded as 2016/TODVAR-5 (0.71) and Roma (0.27). The general mean for this trait was 0.50 . The genotypes viz., Kashi Vishesh (0.66), 2016/TODVAR-3 (0.65), 2015/ TODHYB-1 (0.64), TOLCV-32 (0.59), 2016/TODVAR-12 (0.56) were showed significantly highest values for the trait as compared to general mean. The genotypes, TOLCV-16 (0.47), 2016/TODVAR-11 (0.46), Kashi Amrit (0.44), VRT01 (0.41), Kashi Chayan (0.37), were showed significantly lowest value.

Per se performance of tomato genotypes/varieties for all the quality traits revealed that Kashi Vishesh, Kashi chayan, Roma and Sel-7 were the best, hence these genotypes/varieties can be used as such in promotion of tomato production programme as elite germplasm lines/ varieties or may be recommended for commercial cultivation after testing them over years and locations.

\section{CONCLUSION}

Analysis of variance in the present investigation indicated that the genotypes evaluated differed significantly among all the treatment for all the traits. Among the quality traits, highest TSS content was exhibited by Kashi Aman, Roma, Jawahar-99, Shalimar Hybrid Tomato-1, Kashi Vishesh and Sel-7 whereas highest lycopene content was recorded in 2015/TODHYB-1, Roma, VRT-19, Marglobe and TOLCV-28. Highest ascorbic acid was recorded in Kashi Chayan, Kashi
Hemanth, 2016/TODVAR-1, Jawahar-99 and Sel-7. Highest titrable acidity recorded in Marglobe followed by 2015/ TODHYB-4, Kashi Hemanth, TOLCV-28 and Jawahar-99. Maximum Juice to pulp ratio was recorded in 2016/TODVAR-5 followed by Kashi Vishesh, 2016/TODVAR-3, 2015/ TODHYB-1 and TOLCV-32. The genotypes namely Kashi Vishesh, Kashi chayan, Roma and Sel-7 were performed best for the quality traits under studied. Best performed genotypes on various quality traits, could be used as a source of germplasm for future breeding programmes.

\section{ACKNOWLEDGEMENT}

I am highly thankful to Division of Vegetable science, Division of Plant Breeding and Genetics, Sher-e-Kashmir University of Agricultural Sciences and Technology, Shalimar, Srinagar for providing the facilities for conducting the research.

\section{REFERENCES}

Chada, K.L. (2019). (Revised edition). In: Tomato, Handbook of Horticulture, ICAR Publications, New Delhi. pp 464-470.

Depra, M.S., Delaqua, G.C., Freitas, L. and Cristina, M. (2014). Pollination deficit in open field tomato crops (Solanum lycopersicum L.) in Riode Janeiro State, Southeast Brazil. Journal of Pollination Ecology. 12(1): 1-8.

George, B., Kaur, C., Khurdiya, D.S. and Kapoor, H.C. (2004). Antoioxidants in tomato (Lycopersium esculentum) as a function of genotype. Food Chemistry. 84(1): 45-51.

Gonzalez-Cebrino, F., Lozano, M., Ayuso, M.C., Bernalte, M.J., Vidal-Aragon, M.C. and Gonzalez-Gomez, D. (2011). Characterization of traditional tomato varieties grown in organic conditions. Spanish Journal of Agricultural Research. 9(2): 444-452.

Kaur, R., Savage, G.P. and Dutta, P.C. (2002). Antioxidant vitamins in four commercially grown tomato cultivars. Processing and Nutrition Society of New Zealand. 27: 69-74.

Lee, H.S. (2001). Characterization of carotenoids in juice of red navel orange (Cara Cara). Journal of agriculture and Food Chemistry. 49: 2563-2568.

National Horticulture Board, (2018-19). Data base of Horticultural crops. Gurgaon, Haryana.

Neeraj, S., Ram, C.N., Deo, C., Yadav, G.C. and Singh, D.P. (2015). Genetic variability, Heritability and genetic advance in tomato (Solanum lycopersicum L.). Plant archives. 15(2): 705-709.

Panse, V.G. and Sukhatame, P.V. (1985). Statistical methods for agricultural workers. ICAR, New Delhi.

Pradeep Kumar, T., Bastian, D., Joy, M., Radhakrishan, N.V. and Aipe, K.C. (2001). Genetic variability in tomato for yield and resistance to bacterial wilt. Journal of Tropical Agriculture. 39: 157-158.

Toor, R.K. and Savage, G.P. (2006). Antioxidant activity in different fraction of tomatoes. Food Research International Journal. 38: $487-494$. 